Draft - To appear in M. Evans and P. Koutrakos (Eds.), International Responsibility: EU and International

Perspectives, Oxford: Hart Publishing, 2012 (forthcoming)

\title{
EU Foreign, Security and Defence Policy: A Competence- Responsibility Gap?
}

\author{
Ramses A. Wessel \& Leonhard den Hertog ${ }^{1}$
}

'Europe should be ready to share in the responsibility for global security...'2

\section{Introduction}

Even after twenty years existence of a Common Foreign and Security Policy of the European Union, the division of competences between the Union and its Member States in this area remains unclear. Insight in this division has become more important in view of the increasing role of the EU in global security governance. ${ }^{3}$ Due to its complex and to some extent sui generis nature, the question to which extent the EU would in general be covered by the rules on international legal responsibility has led to some debate. However, most contributions focused exclusively on the European Community, or - later - on the Union's competences on the basis of the TFEU. ${ }^{4}$ The relevance of more clarity regarding the different roles an international organization and its Member States play at the global scene was recently underlined, when the Court of Appeals in The Hague ruled that The

1 Respectively Professor of the Law of the European Union and other International Organizations at the University of Twente, The Netherlands, and EXACT Marie Curie $\mathrm{PhD}$ Fellow at the Universities of Cologne, Germany \& Edinburgh, United Kingdom. The authors wish to thank Christiane Ahlborn (Amsterdam Center for International Law) for her useful comments on an earlier draft of this paper.

2 European Council, European Security Strategy - A secure Europe in a better world, 2003. See also: European Council, Report on the implementation of the ESS - Providing Security in a changing world, 2008, p. 1.

3 See also M Emerson et al., Upgrading the EU's Role as Global Actor: Institutions, Law and the Restructuring of European Diplomacy (Brussels, Centre for European Policy Studies (CEPS), 2011)

$4 \quad$ See E Paasivirta and PJ Kuijper, 'Does one size fit all?: The European Community and the Responsibility of International Organisations' (2007) 36 Netherlands Yearbook of International Law 2005 169; S Talmon, 'Responsibility of International Organizations: Does The European Community Require Special Treatment?', in M Ragazzi (ed), International Responsibility Today (Leiden/Boston, Martinus Nijhoff Publishers, 2005) 405; F Hoffmeister, 'Litigating Against the European Union and its Member States' (2010) European Journal of International Law 723. 
Netherlands was responsible for some actions of military personnel as part of the UN military mission during the Srebrenica crisis in $1995 .^{5}$

The Treaty of Lisbon clarified the international legal status of the European Union by codifying its international legal personality (Article 7 TEU). At the same time it refrained from categorising the nature of the competence under both the Common Foreign and Security Policy (CFSP) and the Common Security and Defence Policy (CSDP) under one of the headings in Title I TFEU: exclusive competences (Article 3), shared competences (Article 4), and competences to support, coordinate, or supplement the actions of the Member States (Articles 5 and 6). Article 2(4) TFEU merely states that a competence exists:" 'The Union shall have competence, in accordance with the provisions of the Treaty on European Union, to define and implement a common foreign and security policy, including the progressive framing of a common defence policy.' One may argue that CFSP and CSDP are not categorised in the TFEU because these policy areas (in contrast to all other policy areas of the Union) do not find their basis in the TFEU, but in the TEU. Yet, even there no express indications can be found as to the type or division of competence we are dealing with in this area. While it may be tempting to argue that we are most probably dealing with a combination of supportive, coordinating, supplementing, or at best shared competences, ${ }^{7}$ the exclusion of mixed agreements calls for international agreements in the area of CFSP and CSDP to be exclusively concluded by the EU. ${ }^{8}$

The purpose of the present contribution is to investigate some questions emerging from the new and ambitious global role of the EU in combination with the unclear division of international responsibility between the EU and its Member States in the area of foreign, security and defence policy. In that sense this paper aims to contribute to the on-going debate on the relationship between international law and

5 Court of Appeals The Hague, Mustafic and Nubanovic [2011] LJN BR0132.

6 Yet, compare the (we would argue, somewhat absurd) view that a CFSP competence as such is lacking as Member States merely use the Union to exercise their own competences. C Hermann, 'Much Ado About Pluto? The Unity of the Legal order of the European Union Revisited', in M Cremona and B de Witte, EU Foreign Relations Law - Constitutional Fundamentals (Oxford, Hart Publishing, 2008) 20.

Cf. M Cremona, 'Defining Competence in EU External Relations', in A Dashwood and M Maresceau (eds.), Law and Practice of EU External Relations: Salient Features of a Changing Landscape (Cambridge, University Press, 2008) 34, 65: '[...] the CFSP appears to be a type of sui generis competence that shares characteristics of both shared and complementary competences'.

8 Cf. RA Wessel, 'The EU as a Party to International Agreements: Shared Competences, Mixed Responsibilities', in A Dashwood and M Maresceau (eds.), Law and Practice of EU External Relations: Salient Features of a Changing Landscape (Cambridge, University Press, 2008) 152, 156-157. 
EU law, ${ }^{9}$ albeit with a strict focus on the perhaps still different position of CFSP and CSDP. As the EU has become increasingly active in global governance, the questions of who takes responsibility (internally) and who can be held responsible (externally) become more important.

The following section will re-assess the division of competences within the postLisbon European Union in the area of CFSP and CSDP. The main question here is who may act under CFSP and CSDP. Furthermore, the analysis will present the international legal framework regarding international responsibility of the EU and its Member States in the area of CFSP and CDSP. In the concluding section we aim to see to which extent there is a fit between internal competences and external responsibility.

\section{Who Acts under CFSP and CSDP?}

\section{A. The Nature of the European Union}

The legal nature of the European Union remains important in order to be able to say something on its possible international responsibility. The Lisbon Treaty not only integrated the European Community into the European Union, but the current Treaty on European Union also explicitly provides that 'The Union shall have legal personality' (Article 7), thus making an end to the academic discussion on the legal status of the Union. ${ }^{10}$ That there is still some uneasiness on the part of some Member States, is reflected in Declaration No. 24, attached to the Lisbon Final Act: 'The Conference confirms that the fact that the European Union has a legal personality will not in any way authorise the Union to legislate or to act beyond the competences conferred upon it by the Member States in the Treaties.' Like many Declarations, this one is also stating the obvious. After all, the principle of attributed (or conferred) powers forms a starting point in international institutional law and is even explicitly referred to in the new TEU, this time with no exception for the (CFSP):

\footnotetext{
9 See in general on this issue: E Cannizzaro, P Palchetti and RA Wessel (eds.), International Law as Law of the European Union (Boston/Leiden, Martinus Nijhoff Publishers, 2011).

10 See on this discussion the many references in RA Wessel, 'The International Legal Status of the European Union' (1997) European Foreign Affairs Review 109; as well as RA Wessel, 'Revisiting the International Legal Status of the EU' (2000) European Foreign Affairs Review, 507.
} 
'Under the principle of conferral, the Union shall act only within the limits of the competences conferred upon it by the Member States in the Treaties to attain the objectives set out therein. Competences not conferred upon the Union in the Treaties remain with the Member States'(Article 5). ${ }^{11}$

Similar careful considerations can be found in Declarations no. 13 and 14, which underline that the changes 'do not affect the responsibilities of the Member States, as they currently exist $[. . .]^{\prime 12}$ and do not 'prejudice the specific character of the security and defence policy of the Member States'.

Hence, since the entry into force of the Lisbon Treaty we are left with one international legal entity: the European Union. And, it is difficult not to regard this entity as an international organization and hence within the scope of the Draft Articles on the International Responsibility of International Organizations (DARIO) as adopted by the International Law Commission (ILC) of the UN in August 2011 and endorsed by the UN General Assembly in December 2011.13 This latest version of the Draft Articles is the latest stage in a development that started in 2002, when the ILC took up this project. The convergence of the 'bits and pieces' that were originally said to make up the Union's structure ${ }^{14}$ has created a new institutional and normative situation. Indeed, the past years revealed that the nature of the Union can best be understood when the complex relation between the different policy areas and between the Union and its Member States is taken into account. ${ }^{15}$ This complex nature has not prevented the Union from becoming an international independent actor'. ${ }^{16}$

11 On the basis of Art. 5 TEU the principles of proportionality and subsidiarity also apply to all Union policy areas, although the Protocol on the Application of the Principles of Subsidiarity and Proportionality seems to focus on 'legislative acts' only and these acts cannot be used for CFSP matters.

12 Emphasis added.

13 International Law Commission (ILC), 'Draft Arts. on the responsibility of international organisations, with commentaries 2011', Adopted by the ILC at its sixty-third session, in 2011, and submitted to the General Assembly as part of the Commission's report covering the work of that session (A/66/10) (2011) Yearbook of the International Law Commission, vol. II, Part Two, 5, see in particular pt. 6 where the Commentary refers to Art. 57 of the Arts. on responsibility of States for internationally wrongful acts. Cf. D Curtin, 'The Constitutional Structure of the Union: A Europe of Bits and Pieces' (1993) CMLR 17.

15 RA Wessel, 'The Dynamics of the European Union Legal Order: An Increasingly Coherent Framework of Action and Interpretation' (2009) European Constitutional Law Review, 117. Compare for a political science perspective also S Stetter, EU Foreign and Interior Policies: Cross-Pillar Politics and the Social Construction of Sovereignty (Oxford, Taylor \& Francis, 2007). The term is used by Paasivirta and Kuijper, above, 181 to differentiate the European Community from more 'classical' international organizations, which are - in their view predominantly a forum for their members. 
Indeed, by now is has become widely accepted that the EU as such may bear international responsibility for an internationally wrongful act. ${ }^{17}$ It seems to fit the definition of an international organization used in the DARIO:

'For the purposes of the present draft articles, the term "international organization" refers to an organization established by a treaty or other instrument governed by international law and possessing its own legal personality. International organizations may include as members, in addition to States, other entities'.

Obviously, the act must be attributable to the EU under international law. ${ }^{18}$ It has been observed that the ILC Draft Articles make no mention of the notion of 'regional economic integration organization' (REIO). ${ }^{19}$ This notion was invented to permit an organization like the EU to participate in multilateral treaties and conventions as a contracting party alongside states. ${ }^{20}$ In the absence of special rules for the EU, we will follow the general rules on responsibility of international organizations in our assessment of the responsibility of the EU and its Member States in the area of foreign, security and defence policy.

\section{B. The Legal Nature of the External Competence: CFSP}

Although 'the nature of the Union's external competence is an important factor in the allocation of international responsibility', ${ }^{21}$ this nature is not so easy to establish in the area of foreign, security and defence policy. As indicated above, both CFSP and CSDP are not mentioned in the categorisation of competences in Article 3 TFEU. There are indeed good reasons to argue in favour of a 'shared competence' external action in this area. A shared competence allows both the Union and its Member States to take the necessary decisions, but Member States' competences may be exercised only to the extent that the Union has not exercised its competence (Article 2, paragraph 2 TFEU). In fact, it could be argued that this is the case in CFSP. Although there are good reasons to presume that pre-emption does not

17 Cf. Hoffmeister, above, 724.

18 Chapter II of the ILC Draft Arts. deals with the question of attribution.

19 The 2004 Energy Charter Treaty (Art. 3) defines a REIO as 'an organization constituted by states to which they have transferred competence over certain matters a number of which are governed by this Treaty, including the authority to take decisions binding on them in respect of those matters.'

$20 \quad$ Paasivirtaa and Kuijper, above, 205.

$21 \quad$ Hoffmeister, above, 743. 
apply to CFSP, ${ }^{22}$ it is equally difficult to maintain that established CFSP decisions and international agreements do not at all restrict Member States' freedom to act externally. As argued elsewhere, possible internal restraints on Member States' freedom to conclude international agreements in CFSP fields can stem from both CFSP treaty norms and CFSP secondary measures. The degree of restraining effect of those CFSP norms is also determined by the potential role that the judiciary may play in ensuring that those norms are enforced, as well as the interpretation given to the specific CFSP principle of loyal cooperation. ${ }^{23}$ As 'rules of the organization' (see section II below) these restraints may play a role in establishing responsibilities.

In that sense, the effect of CFSP norms on Member States' powers could be envisaged in the light of the Court's pronouncements on the effects of Community powers in the fields of development cooperation or humanitarian aid. This case law suggests that since the Community competence in these fields is not exclusive but 'parallel', the Member States are accordingly entitled to enter into commitments themselves vis-à-vis non-Member States, either individually or collectively, in the Council or outside it, or even jointly with the Community. ${ }^{24}$ If we would accept the idea of 'shared' competences under CFSP, Member States would have less room for manoeuvre. Could this even lead to 'exclusivity' in relation to CFSP? Article 3, paragraph 2 TFEU reads:

'The Union shall also have exclusive competence for the conclusion of an international agreement when its conclusion is provided for in a legislative act of the Union or is necessary to enable the Union to exercise its internal competence, or insofar as its conclusion may affect common rules or alter their scope'.

Indeed, CFSP rules will not find their basis in a 'legislative act'. ${ }^{25}$ That being said, when this provision is read in conjunction with the loyalty principle enshrined in Article 28, paragraph 4 TEU, it seems too early to rule out exclusivity in the field of CFSP completely, particularly in view of the fact that the Court would have

22 See Cremona, above, 65 as well as D Thym, 'The Intergovernmental Constitution of the EU's Foreign, Security \& Defence Executive' (2011) EUConst 453.

23 C Hillion and RA Wessel, 'Restraining External Competences of EU Member States under CFSP', in M Cremona and B De Witte (eds.), EU Foreign Relations Law: Constitutional Fundamentals (Oxford, Hart Publishing, 2008) 79.

24 Joined Cases C-181/91 and C-248/91 European Parliament v Council of the European Communities and Commission of the European Communities [1993] ECR I-3685 (Bangladesh case); Case C-316/91 European Parliament v Council of the European Union [1994] ECR I-625 (EDF case). See Arts. 24(1) TEU and 298(3) TFEU. 
jurisdiction in respect of this Article. After all, the Union's external activities in the form of the conclusion of international agreements are booming and Member States' actions increasingly risk affecting common rules or altering their scope. While the creation of CFSP norms depends on the political will of the Member States, once these norms have been established, their very purpose is to restrict the freedom Member States traditionally enjoy in their external relations. Allowing Member States to affect - or even act contrary to - common norms established by EU international agreements would amount to rendering most of the CFSP and CSDP provisions in the EU Treaty nugatory.

Also in relation to possible international responsibility, the emerging question is whether a hierarchy of competences can be established: to what extent are Member States bound by agreements concluded by the Union, and do these agreements restrict their individual freedom in external relations? In this respect, there appears to be no reason not to apply the so-called Haegeman doctrine to CFSP agreements and to regard them as forming 'an integral part of Union law'. ${ }^{26}$ Article 216(2) TFEU indeed states that Member States are automatically bound by the agreements as a matter of EU law and vis-à-vis the EU. The question remains whether perhaps a 'direct effect' of the agreements could even be construed. ${ }^{27}$ This would place the Member States in a different position towards the agreements than in other international organisations. Yet, no a priori external effects result from this. ${ }^{28}$

\section{To What Extent are Member States Bound by EU External Action?}

Indeed, apart from the question on the nature of the competence, the question who is bound (internally, inside the EU) by international agreements (and perhaps decisions) concluded in the area of CFSP and CSDP seems important to be able to assess the division of possible international responsibility.

\footnotetext{
26 As provided by the ECJ in relation to international agreements concluded by the European Community: Cases C-181/73 Haegeman [1974] ECR 449 and C-104/81 Kupferberg [1982] ECR 3641. See in the same line D Thym, 'Die völkerrechtlichen Verträge der Europäischen Union' (2006) 66 Zeitscbrift für ausländisches öffentliches Recht und Völkerrecht 900.

27 See for a negative answer to this question Thym, 'The Intergovernmental Constitution', above

28 Cf. also the Drafting history of the infamous Arts. 36 bis of the 1986 Vienna Convention on the Law of Treaties. C Bröllmann, The Institutional Veil in Public International Law: International Organisations and the Law of Treaties (Oxford, Hart Publishing, 2007).
} 
In the area of CFSP and CSDP, international agreements are concluded by the Union. The Union has made full use of its competence in this area. ${ }^{29}$ By using the pre-Lisbon Article 24 TEU competence (in conjunction with Article 38 TEU in the case of agreements in the area of police and judicial cooperation in criminal matters), the European Union has entered the international stage as a legal actor with obligations and responsibilities. This turned the provision into the general legal basis for the Union's treaty making whenever agreements could not be based on the Community Treaty. These days, the competence to conclude international agreements can be found in one single legal basis for the entire Union: Article 216 TFEU, which provides:

'The Union may conclude an agreement with one or more third countries or international organisations where the Treaties so provide or where the conclusion of an agreement is necessary in order to achieve, within the framework of the Union's policies, one of the objectives referred to in the Treaties, or is provided for in a legally binding act of the Union or is likely to affect common rules or alter their scope.'

That this competence stretches beyond the TFEU itself and includes the domain of CFSP is underlined by Article 37 TEU, which provides that 'the Union may conclude agreements with one or more States or international organisations in areas covered by this Chapter' (named 'Specific provisions on the Common Foreign and Security Policy'). ${ }^{30}$

All international agreements are, in the end, concluded by the Council. ${ }^{31}$ In contrast to other Union areas, no mixed agreements are concluded in the area of CFSP and

29 Cf. A Sari, 'The Conclusion of International Agreements by the European Union in the Context of the ESDP' (2008) International and Comparative Law Quarterly 53; P Koutrakos, 'International Agreements in the Area of the EU's Common Security and Defence Policy', above; and RA Wessel, 'The EU as a Party to International Agreements: shared competences, mixed responsibilities', in A Dashwood and M Maresceau (eds.), Law and Practice of EU External Relations (Cambridge, University Press, 2008) 152. Indeed, these 'agreements' can be considered treaties in the sense of Art 2(1)(a) of the 1969 and 1986 Vienna Conventions on the Law of Treaties as they fulfil all generally accepted criteria. See, in general, A Aust, Modern Treaty Law and Practice (Cambridge, University Press, 2007); and J Klabbers, The Concept of Treaty in International Law (The Hague, Kluwer Law International 1996). Most agreements can be found in the international agreements database of the Commission (http://ec.europa.eu/world/agreements/).

This Chapter (2) also includes Section 2: Provisions on the Common Security and Defence Policy.

31 The debate on whether these agreements are concluded by the Council on behalf of the Union or on behalf of the Member States seems not only to be superseded by practice but also accepted by most experts in EU external relations law. Cf. R Gosalbo Bono 'Some 
CSDP. In fact, the entire decision-making process as well as the conclusion of the agreement does not reveal a separate role for the Member States. Apart from the references to the EU in both the texts and the preamble of the agreements and the fact that adoption and ratification is done 'on behalf of the Union', this is confirmed by the central role of the Union's institutions and organs, and the final publication in the L-series of the Official Journal (decision on inter se agreements of the Member States are published in the C-series). Indeed, 'fairly strange operations would be needed to demonstrate that a treaty concluded under such circumstances has instead created legal bonds between the third party concerned and each one of the Member States of the European Union'.32

Nevertheless - and in line with our observations in the previous section - internally both the Union and its Member States seem to be bound by the agreements. This is underlined by Article 216, par. 2, which simply states: 'Agreements concluded by the Union are binding upon the institutions of the Union and on its Member States.' Prima facie, for third parties this does not change anything: only obligations for the EU arise from these international agreements and Member States obligations subsequently follow on the basis of Union law. At the same time, the question emerges whether this provision would play a role in the light of the special position of 'the rules of the organization' in the law on the responsibility of international organizations (infra). ${ }^{33}$

EU external action, however, not only takes shape in the form of international agreements. International responsibility may be triggered on the basis of a number of other actions and situations, including the external effects of CFSP decisions,

Reflections on the CFSP Legal Order' (2006) CMLRev, 354; Thym, 'Die völkerrechtlichen Verträge der Europäischen Union', above, 863; C Tomuschat, 'The International Responsibility of the European Union' in E Cannizzaro (ed), The European Union As an Actor in Intermational Relations (The Hague, Kluwer Law International, 2000) 181; RA Wessel, 'The EU As a Party to International Agreements: Shared Competences? Mixed Responsibilities?' in A Dashwood and M Maresceau (eds), The Law and Practice of EU External Relations - Salient Features of a Changing Landscape (Cambridge, University Press, 2008) 145; and RA Wessel and G Fernandez Arribas, 'EU Agreements with Third Countries: Constitutional Reservations by Member States' in S Blockmans (ed), The European Union and International Crisis Management: Legal and Policy Aspects (The Hague, TMC Asser Press, 2008) 291.

32 C. Tomuschat, 'The International Responsibility of the European Union', above, 181-2. Cf. also P Eeckhout, External Relations of the European Union (Oxford, University Press, 2004) 159; P Koutrakos, EU International Relations Law (Oxford, Hart Publishing, 2006) 406-9 and Gosalbo Bono, 'Some Reflections', above, 354-6.

33 See extensively on these rules: C Ahlborn, 'The Rules of International Organizations and the Law of International Responsibility' (2011) to be published in International Organizations Law Review. 
CSDP actions and missions and the participation of the EU in international organizations. ${ }^{34}$ Within the limited scope of the present chapter we will only be able to touch upon some of these issues.

\section{EU External Action and International Responsibility}

In our assessment of the applicable rules we will follow the Draft Articles on the Responsibility of International Organizations, adopted on second reading in 2011. On the basis of Article 1, the Draft Articles 'apply to the international responsibility of an international organisation for an internationally wrongful act'; as well as 'to the international responsibility of a State for an internationally wrongful act in connection with the conduct of an international organisation'. ${ }^{35}$ Not being dealt with in the Articles on the responsibility of states for internationally wrongful acts, the latter paragraph is meant to inter alia incorporate those cases of State responsibility for internationally wrongful acts by an international organisation where a State is a member of that organisation, such as the Member States of the Union. ${ }^{36}$

The DARIO suggest as a point of departure that the EU is responsible for its own internationally wrongful acts. Draft Article 3 states: 'Every internationally wrongful act of an international organization entails the international responsibility of that organization'. Article 4 lists the conditions for an internationally wrongful act by an international organization that entails the international responsibility of that organization: "There is an internationally wrongful act of an international organization when conduct consisting of an action or omission: (a) Is attributable to the international organization under international law; and (b) Constitutes a breach

34 See on the latter KE Jørgensen and RA Wessel, 'The Position of the European Union in (other) International Organizations: Confronting Legal and Political Approaches', in P Koutrakos (ed.), European Foreign Policy: Legal and Political Perspectives (Chaltenham, Edward Elgar Publishers, 2011) 261.

The wording of this second paragraph used to read (in the 2009 version): 'The present draft articles also apply to the international responsibility of a State for the internationally wrongful act of an international organisation' [Emphasis added]. One may assume that the wording was changed since the conduct of the international organisation need not necessarily be wrongful, for example in the case of coercion. The authors thank Christiane Ahlborn (PhD Researcher, University of Amsterdam) for this valuable comment. See for the previous version of the Draft Arts.: ILC, 'Draft Arts. on the Responsibility of International Organisations' (2009) Report of the International Law Commission on the Work. of its $61^{\text {st }}$ session, UN Doc. A/C.6/64/10, 39.

36 See in particular pt. 6 of the DARIO Commentaries where the Commentary refers to Art. 57 of the Arts. on responsibility of States for internationally wrongful acts. 
of an international obligation of that organization'. The next question is what conduct can be attributed to the Union.

According to Draft Article 6(1):

'The conduct of an organ or agent of an international organization in the performance of functions of that organ or agent shall be considered an act of that organization under international law, whatever position the organ or agent holds in respect of the organization.'

This somewhat obvious rule indicates that conduct by organs and agents can establish the international responsibility of the Union. According to Draft Article $6(2)$, the 'rules of the organisation' shall be applied when determining the 'organs and agents'. ${ }^{37}$ In view of the Union rules on 'internal' responsibility, there are good reasons to interpret the term 'organs and agents' as 'institutions, bodies, offices and agencies and their servants' as used is in the TFEU. ${ }^{38}$ In any case, as is suggested by the broad definitions of 'organs and agents' in Draft Articles 2(c) and (d), the Draft Articles do not envisage the attribution of conduct to 'depend on the use of particular terminology in the internal law' of the Union. ${ }^{39}$

In the area of CFSP/CSDP this would thus cover not only conduct of the Council, but also of the High Representative of the Union for Foreign and Security Policy, the Political and Security Committee (PSC), the EU External Action Service (EEAS), agencies, such as the European Defence Agency or the EU Institute for Security Studies and of individual representatives in the framework of EU's CFSP. It would also include the EU delegations (transformed from 'Commission delegations' as they existed in the pre-Lisbon era) and civilian and military missions. However, these missions are probably better covered by Article 7, as discussed below. At the same time, however, Article 6 also raises the question of whether

37 This is not the only criterion however, as in exceptional circumstances, functions may be considered as given to an organ or agent even if this could not be said to be based on the rules of the organisation': Draft Arts. with commentaries, above, 19. Cf. Hoffmeister, above, 740, who refers to Arts. 340(2) and 263 TFEU as well as to Art. 51(1) of the EU Charter of Fundamental Rights. Art. 10(2) confirms that also 'the breach of any international obligation that may arise for an international organisation towards its members under the rules of the organisation' is included in the Draft Arts. Ahlborn argues that this second paragraph could have been deleted, see: C Ahlborn, above.

Draft Arts. with commentaries, above, 17. The commentary invokes also some case law on the point such as the ICJ Advisory Opinion, Reparation for injuries suffered in the service of the United Nations, ICJ Reports 1949, 177, where the Court held that an agent is 'any person through whom it [the international organisation] acts'. 
Member States could, in certain cases, be seen as organs or agents of the Union. ${ }^{40} \mathrm{It}$ is here that some argue, although it is not expressly acknowledged by the ILC, ${ }^{41}$ that the 'organic link' between an IO and Member States is relevant. ${ }^{42}$ For example, as even the ILC Rapporteur acknowledges, ${ }^{43}$ WTO case law accepted Member States as 'organs' and 'agents' of the Union in several instances. ${ }^{44}$ Moreover, from inter alia EU case law it can be deduced that the notion of 'normative control' by the Union over its Member States is relevant to establish an 'organ' or 'agent' situation, even if the Member State action merely 'falls in the scope of Union law' (as opposed to situations of MS implementing Union law). Hoffmeister describes these situations as those in which 'the Member States are under a duty not to overstep certain boundaries set by Union law' and concludes from EU case law that 'when it is established that Union law governs both the substantive legality of and the available remedies for a measure, then the Union exercises normative control over it.' ${ }^{2}$ 'This EU case law is relevant, especially in light of the increased importance of 'rules of the organisation' in the 2011 Draft Articles. ${ }^{46}$ In the area of CFSP these cases would arguably be rare, but cannot be fully ruled out. An example could be Member State conduct vis-à-vis a third State falling in the scope of a CFSP agreement concerning the exchange and protection of classified information. ${ }^{47}$

Moreover, Draft Article 7 makes clear that:

'The conduct of an organ of a State or an organ or agent of an international organization that is placed at the disposal of another international

Although 'the distinction between organs and agents does not appear to be relevant for the purpose of attribution of conduct to an international organisation', the 'agent' definition 'only covers persons or entities which do not come within the definition under subparagraph (c) [that of 'organ']: Draft Arts. with commentaries, above, resp. 18 \& 12 .

Even more, the ILC stated in 2005 that 'it seems preferable at the current stage of judicial developments not to assume that a special rule has come into existence to the effect that, when implementing a binding act of the European Community, State authorities would act as organs of the European Community'; ILC, Report of the fifty-seventh session, Responsibility of international organisations (2005) UN Doc. A/60/10, Commentary on Part One, Chapter IV, 95, para. 7. However, since then the ILC has become 'less categorical', see Hoffmeister, above, 729 . See Ahlborn, above, 37.

Draft Arts. with commentaries, above, 101. See e.g. WTO Panel, Protection of Trademarks and Geographical Indications for Agricultural Products and Foodstuffs (adopted 20 April 2005) WT/DS174/R, para. 7.725. For a more WTO case law see Hoffmeister, above, 371-374.

45 Hoffmeister, op. cit., at. 741 and 742.

46 First of all, the 'rules of the organisation' are mentioned in Art. 6(2) itself. However, the 'lex specialis' of Art. 64 (see last sentence) also acknowledges that the 'rules of the organisation' may

See for example the EU-Russia agreement on this matter: Agreement between the Government of the Russian Federation and the European Union on the protection of classified information, OJ L155/57. 
organization shall be considered under international law an act of the latter organization if the organization exercises effective control over that conduct.'

The question, however, is whether the term 'placed at the disposal of' an international organization is applicable at all to the general relationship between the EU and its Member States. Only then would the question whether the EU exercises effective control over the conduct of its Member States in the area of CFSP and CSDP be relevant. ${ }^{48}$ The question has been addressed in relation to the European Community, and there seems to be a consensus that the idea of 'effective control' was not relevant when authorities of Member States merely carry out Community law. ${ }^{49}$ Much more importantly however, as the commentaries to Article 7 reveal, this provision is most relevant in relation to civilian and military operations. ${ }^{50}$ This Article deals with the 'situation in which the seconded organ or agent still acts to a certain extent as organ of the seconding State' which 'occurs for instance in the case of military contingents that a State places at the disposal of the United Nations for a peacekeeping operation, since the State retains disciplinary powers and criminal jurisdiction over the members of the national contingent'. ${ }^{1}$ In contrast to 'normative control' as discussed above, the de facto effective operational control of the missions is the deciding factor here. ${ }^{52}$ The commentaries, by thoroughly analysing case law and UN legal opinions, reveal that for UN peacekeeping missions (in contrast to UN Security Council authorised military action) the UN will in principle bear responsibility, as it exercises effective control. ${ }^{53}$ It is tempting to apply this argument mutatis mutandis to CSDP missions. After all, these missions may be under operational control of the EU, through CSDP bodies of the PSC, EUMC (Military Committee), EUMS (Military Staff) and the CPCC (Civilian Planning and Conduct Committee). However, attribution to the $\mathrm{IO}$ is no rigid rule, as the above-mentioned

$48 \quad$ See Chapter $\mathrm{X}$ by Tomuschat in this volume.

49 See Paasivirta and Kuijper, above; as well as PJ Kuijper, 'Introduction to the Symposium on Responsibility of International Organizations and of (Member) states: Attributed or Direct Responsibility or Both?' (2010) International Organizations Law Review 9. The commentaries to Art. 7 deal extensively with those missions, in the context of UN missions. See: Draft Arts. with commentaries, above, 19-26. Hoffmeister also concludes that Art. 7 'was mainly written to codify the rule relating to the international responsibility of the United Nations (or regional organisations) for a military operation using the forces of its Member States': Hoffmeister, above, 726. See Draft Arts. with commentaries, above, 20. ibid: 'The criterion for attribution of conduct either to the contributing State of organisation or to the receiving organisation is based according to Art. 7 on the factual control that is exercised over the specific conduct taken by the organ or agent placed at the receiving organisation's disposal'.

53 Ibid, 19-26. See also on this point: Blokker, above, 47. In the commentaries, the ILC also critiques, as do many academics, the ECtHR position on 'effective' and 'ultimate' control in the Behrami, Behrami and Saramati cases, see: Draft Arts. with commentaries, above, 23 and ftnt. 115 for a long list of critical academic contributions. 
Srebrenica judgments revealed. A case-by-case analysis and application of the 'effective control' concept is crucial. ${ }^{54}$

Of possible relevance to the situation in CFSP and CSDP is Article 9 of the Draft Articles. On the basis of this Article conduct can also be considered as act of an international organization 'if and to the extent that the organization acknowledges and adopts the conduct is question as its own'. This article applies only in cases where 'Conduct $[\ldots]$ is not attributable to an international organizations under articles 6 to 8 ' and could therefore be seen as an addendum to the general rules of attribution. The situation is mirrored by Article 62, which states that a Member State of an international organization is responsible for an internationally wrongful act of that organization if: '(a) It has accepted responsibility for that act towards the injured party; or (b) It has led the injured party to rely on its responsibility.' The subsidiary nature of this Article 62 responsibility allows for a shared responsibility of the organization and its Member States (as do the other Articles on responsibility), in contrast to the attribution of conduct under Article 9 (as the other Articles on conduct). ${ }^{55}$ Although it would be rare for a Member State to expressly accept responsibility for a wrongful act of the EU, the commentaries (rather vaguely) suggest that 'acceptance' should be widely interpreted. Hence, acceptance may also be 'implied' or could result 'from the constituent instrument of the international organisation or from other rules of the organisation'. ${ }^{56}$ Interestingly enough, the commentaries briefly discuss the example of Article 216 TFEU, which states inter alia that the Member States are bound by EU international agreements, as an example of how this would not amount to 'acceptance'. This is only binding 'towards the organisation' and does not 'produce legal effects in relation to third parties', as the ECJ also held before. ${ }^{57}$

In the area of CFSP it would be difficult to find 'valid' cases of acceptance. With regard to the second 'option' of Article 62 - namely that a Member State 'has led the injured party to rely on its responsibility' - the commentaries take an identical wide interpretation of 'reliance'. It puts forward a scenario which is not wholly

\footnotetext{
$54 \quad$ See further on this issue: A. Sari and R.A. Wessel, 'International Responsibility for EU Military Operations: Finding the EU's Place in the Global Accountability Regime', in B. Van Vooren, S. Blockmans and J. Wouters (Eds.), The Legal Dimension of Global Governance: What Role for the EU? (Oxford, Oxford University Press, 2012, forthcoming)

55 See also Kuijper, above, 19 and Hoffmeister, above,727. See also Draft Arts. 19 \& 63 which stipulate the additional nature of the responsibility Arts. under resp. Part Two, Chapter IV and Part Five.

56 Draft Arts. with commentaries, above, 97, emphasis added.

57 Ibid, 97, ftnt 356. See also: ECJ, France v Commission [1994] ECR I-3641, I-3574, para. 25 .
} 
illusory in CFSP, namely when a third party has been led to 'reasonably assume that they [the Member States] would stand in if the responsible organisation did not have the necessary funds for making reparation. ${ }^{58}$ As CSDP missions are in principle Member State funded, a third party could reasonably assume that the Member States will also stand in if a wrongful act is committed in the course of the mission and reparation has to be paid. Moreover, Draft Article 40(2) stipulates that 'the members of a responsible international organisation shall take all the appropriate measures that may be required by the rules of the organisation in order to enable the organisation to fulfil its obligations under this Chapter [dealing with reparation].' Thus, the Member States may also be 'drawn into' the reparation for Union responsibility even if they bear no responsibility for it.

The responsibility of the Union in relation to the role of the Member States is indeed at the core of our topic and is most prominently dealt with in Draft Article 17. ${ }^{59}$ What happens if the Union adopts a CFSP or CSDP decision which would force (or authorize) the Member States to commit an internationally wrongful act? Article 17 foresees a number of situations:

'1. An international organization incurs international responsibility if it circumvents one of its international obligations by adopting a decision binding member States or international organizations to commit an act that would be internationally wrongful if committed by the former organization.

2. An international organization incurs international responsibility if it circumvents one of its international obligations by authorizing member States or international organizations to commit an act that would be internationally wrongful if committed by the former organization and the act in question is committed because of that authorization.

3. Paragraphs 1 and 2 apply whether or not the act in question is internationally wrongful for the member State or international organizations to which the decision or authorization is directed.'

Hence, the European Union itself could incur international responsibility both in the case of binding decisions addressed to the Member States and when the latter act because of an authorization by the Union. It is important to realise that this Article

58 Draft Arts. with commentaries, above, 98.

59 See NM Blokker, 'Abuse of the Members: Questions concerning Draft Art. 16 of the Draft Arts. on Responsibility of International Organizations' (2010) International Organizations Law Revien 35; as well as J d'Aspremont, 'Abuse of the Legal Personality of International Organizations and the Responsibility of Member States' (2007) International Organizations Law Review 91. 
applies to 'circumvention' by the Union and that hence the conduct of the 'implementing' Member State itself need not necessarily be unlawful; it is the binding or 'authorising act' of the Union that, if it were to implement that itself, should qualify as unlawful. ${ }^{60}$

At the same time, Member States may be responsible once they hide behind an international organization. Article 61 provides:

'1. A State member of an international organization incurs international responsibility if, by taking advantage of the fact that the organization has competence in relation to the subject-matter of one of the State's international obligations, it circumvents that obligation by causing the organization to commit an act that, if committed by the State, would have constituted a breach of the obligation.

2. Paragraph 1 applies whether or not the act in question is internationally wrongful for the international organization.'

As Kuijper rightfully argues:

'This article sets out a series of events that virtually no State could bring about all on its own, since it would need at least several other States as "partners in crime" in order to incite the organization from the inside to commit an act contrary to the Member States' international obligations to which the organization would not be bound. ${ }^{61}$

Moreover, the EU would have to act not in its 'rule-making capacity' in the Article 17 situation, which is well imaginable, but in an 'operational capacity' in the Article 61 situation, something which is less common. ${ }^{62}$ Nevertheless, also in the relationship between the EU and its Member States in the area of CFSP/CSDP these types of 'abuse' are not to be ignored completely. For example, in contrast with the Member States, the EU is not Party to the Geneva Refugee Convention. Hypothetically, the Member States could then attempt to circumvent their obligations under that treaty, namely 'using' a CSDP mission to act in contravention of the principle of nonrefoulement in order to stop migration flows, for example in a maritime CSDP

60 Draft Arts. with commentaries, above, 40-42.

61 Kuijper, above, 28. See more extensively on Art. 60: E Paasivirta, 'Responsibility of a Member States of an International Organization: Where Will it End? Comments on Art. 60 of the ILC Draft on the Responsibility of International Organizations' (2010) International Organizations Law Review 49. Kuijper, above, 28. 
mission. ${ }^{63}$ It is in particular in this area where the debate on the Union's separate international legal status finally led to an acceptance of the legal personality of the European Union, including all its policy areas. It is in fact the existence of this international legal personality alongside the legal personalities of the Member States that potentially allow both to play 'hide and seek'.

A number of other, general, situations may be relevant in establishing the division of responsibilities between the EU and its Member states in the area of foreign, security and defence policy. These situations do not concern the specific relation between the organisation and its Member States, but relate more generally to relationships between international organizations and states. Nevertheless, we briefly address them here as 'Member States' are not excluded from the definition of a 'State'. ${ }^{64}$

First, Article 14 of the Draft Articles states that:

'An international organization which aids or assists a State or another international organization in the commission of an internationally wrongful act by the State or the latter organization is internationally responsible for doing so if: (a) the former organization does so with knowledge of the circumstances of the internationally wrongful act; and $(b)$ the act would be internationally wrongful if committed by that organization.' 65

The mirror image is provided by Article 58, paragraph 1, which establishes under the same conditions the international responsibility of 'a State which aids or assists an international organization in the commission of an internationally wrongful act [...]'. Given the close cooperation between the Union and its Member States in the formulation and implementation of CFSP and CSDP these provisions are relevant. It has been suggested elsewhere that this 'aiding or assisting' may also well take

63 In the Mediterranean context it is not wholly unimaginable that a CSDP mission would come to deal with migrant boats on the move to the EU, as NATO did in 2011. One such incident, under which NATO did allegedly not live up to international search and rescue obligations leading to the death of 61 migrants, is currently being investigated by the Migration Committee of the Parliamentary Assembly of the Council of Europe. See: http://assembly.coe.int/ASP/NewsManager/EMB NewsManagerView.asp?ID=6789\&L $\equiv 2$

64 In fact, 'States' are not defined at all and are not referred to in Draft Art. 2, which defines 'International organization', 'Rules of the organization', and 'Agents'.

65 Emphasis added. 
financial forms. ${ }^{66}$ Due to the peculiar funding structure of CSDP missions - the Member States fund in principle the EU Missions - this may be a possible area of attention under Article 58.

A similar situation concerns the responsibility of an international organization that directs and controls a state (or another international organization) in the commission of an internationally wrongful act. ${ }^{67}$ This is dealt with in Article 15 of the Draft Articles. Again a mirror image can be found, which provides that:

'A State which directs and controls an international organization in the commission of an internationally wrongful act by the latter is internationally responsible for that act if: (a) the State does so with knowledge of the circumstances of the internationally wrongful act; and $(b)$ the act would be internationally wrongful if committed by that State.' (Article 59, paragraph 1).

A situation in which Member States direct or control the EU in the execution of CFSP/CSDP may be difficult to find, but it is has been suggested that excessive control over the decision-making process of an organization could lead to (joint) international responsibility. ${ }^{68}$ Obviously, this would be difficult to reconcile with the idea of Member States as 'seat holders' in an organ of an international organization, in which view the decision-making procedure as such is irrelevant as in the end it is the organization that takes the decision. ${ }^{69}$ Situations in which Member States are directed or controlled by the Union form the foundation of the CFSP. International wrongful acts by states on the basis of binding CFSP/CSDP decisions are thus not excluded.

To the abovementioned Articles dealing with State responsibility for aiding, assisting, directing and controlling the conduct of international organisations (Articles 58 \& 59), the ILC has added a second paragraph in the 2011 version of the Draft Articles which reads: 'An act by a State member of an international organisation done in accordance with the rules of the organisation does not as such engage the international responsibility of that State under the terms of this draft

66 A Reinisch, 'Aid or Assistance and Direction and Control between States and International Organizations in the Commission of Internationally Wrongful Acts' (2010) International Organizations Law Review 70.

67 See more extensively: Ibid.

68 J d'Aspremont, above, 92: '[...] member states exerting an excessive control over the decision-making process of the organization must be held, together with the organization, responsible for violations of international law committed by the organization'

69 RA Wessel, 'Revisiting the International Legal Status of the EU' (2000) European Foreign Affairs Review, 507, 516. 
Article. ${ }^{70}$ This addition raises the importance of the 'rules of the organisation' as they suggest that it could prevent the international State responsibility from arising if the Member States acts in accordance with them. However, it seems to the authors that it could also potentially undermine the authority of the Draft Articles, as it seems to allow for a 'way out'. Could it possibly mean that, if Member States act on the basis of a CFSP decision, in accordance with EU law, they would not be held responsible under Articles 58 and 59? The commentary indicates that 'These criteria could entail some difficulties in ascertaining whether aid or assistance has taken place in borderline cases' and that this 'does not imply that the State would then be free to ignore its international obligations'. This is akin to statements in ECtHR judgements, such as in the Bosphorus where the Court held that Member States cannot escape scrutiny by 'hiding' behind the EU to which competences were transferred. ${ }^{71}$ The commentaries go on to state that such international obligations 'may well encompass the conduct of a State when it acts within an international organisation', thus leaving the boundaries between international and internal' EU law nebulous for the present purposes. Clearly, there is a dilemma here for the ILC or at least a paradox for the reader. The commentaries then finish by saying that if such a situation would occur, the Member States would still be liable, but under the Articles on the responsibility of States for internationally wrongful acts. ${ }^{72}$ To the authors it is rather unclear how this latest addition to the DARIO contributes to a clearer delimitation of responsibility.

The Draft Articles foresee situations in which either the organization or the state is subject to coercion by the other. The applicable rules can be found in Draft Articles 16 and 60 . In view of the theoretical nature of these provisions with regard to the relationship between the EU and its Member States, we leave this possibility out of our discussion.

Finally it should be pointed out that a 'lex specialis' has been added in Article 64 of the Draft Articles which stipulates that the these Articles will not apply if 'special rules of international law' such as 'rules of the organisation applicable to the relations between an international organisation and its members' cover the responsibility questions. The Commentaries discusses a specific example under which these 'rules of the organisation' may come into play: the European Union and its Member States. ${ }^{73}$ It is thus here that - as we have seen before - the internal rules

Emphasis added.

See: 30 June 2005, Application No. 45036/98, Bosphorus v Ireland.

Draft Arts. with commentaries, above, 91.

Ibid, 100-101. 
of the Union, including those on competences, may make their way into questions of international responsibility.

\section{Conclusion: A Competence-Responsibility Gap?}

A first glance at the division of international responsibility between the EU and its Member States suggests that the EU itself would be primarily responsible for any international wrongful acts in the area of foreign, security and defence policy. What kind of internationally wrongful act could this be? Obviously, not living up to international agreements concluded with third states or other international organizations could result in such international responsibility. Also acts by any agent of the Union (e.g. the Institutions, but also the High Representative, Special Envoys and CSDP missions) which would be in violation of international obligations would be attributable to the Union. Given the upgraded role for the EU in global governance, more rules have become applicable to its actions.

While one could perhaps argue that there once was a difference between Community law and CFSP law, at least post-Lisbon it has become difficult to maintain that the constitutional relationship between the Union and its Member States differs on the basis of a policy area. ${ }^{74}$ So far, however, this special relationship between the EU and its Member States is not reflected in the Draft Articles. As we have seen, the 'effective (of 'factual') control' argument may be decisive in establishing the division of responsibility between the EU and its Member States in very concrete situations in the framework of EU military missions, but the complex nature of CSDP decision-making and implementation calls for a case-by-case analysis which is to take account of the special position Member States have in conducting EU military missions. With its focus on the agency paradigm of attribution, the DARIO's relevance may be limited in relation to CSDP missions. ${ }^{75}$

Indeed, the complex nature of the cooperation between the EU and its Member States in external situations is not only related to the division of competences, but

\footnotetext{
74 More extensively: RA Wessel, 'The Dynamics of the European Union Legal Order', above. But see for instance Kuijper, above, 21, who argues that 'the divide on this point runs right across the EU, separating its traditionally supra-national EC part from the intergovernmental CFSP-side'. In his view 'the foreign policy powers of Member States are unaffected by the fact that certain aspects of foreign- and defense policy are run on a common basis' (at 20, fn. 36). Cf. also Thym, above, 454, who accepts the 'horizontal constitutionalisation' (the same constitutional control standards apply to all areas of Union action), but maintains that Union law is of a different nature in CFSP and CSDP, where it is 'a manifestation of intergovernmental executive power', rather than 'law-making'. 
also to the actual use of these competences in concrete situations. This allegedly makes the assessment of international responsibility even more difficult. Even after almost twenty years of CFSP, we have not been able to fully grasp the complexity of the relationship between the EU and its Member States relationship in this area. Yet, with the increasing external activity of the Union, there is a need to become more precise.

In general, the rules in the TEU provide no indications for a conclusion that in CFSP/CSDP the Member States would by definition be the first ones to incur international responsibility. This would be confirmed by the specific rules on the conclusion of EU international agreements, which uniformly cover both CFSP and non-CSFP agreements. As most EU external action is based on international agreements, this would not amount to a competence-responsibility gap. Yet, as we have seen, in the area of CSDP in particular, it may not always be easy to establish the actual competence and responsibilities depend on more than just competences.

From our analysis, the contours of how internal CFSP competences influence the external responsibility under the DARIO emerge. Although we have seen that the Union incurs responsibility, as a point of departure, the specific CFSP/CSDP 'rules of the organisation" 76 allow for more complex situations. The internal division of competences therefore 'pierces' the institutional veil of the Union, inter alia via the acknowledgement of the 'rules of the organisation'. For example, the 'rules of the organisation' are important in determining whether Member States could be seen as agents or organs of the Union (cf. Article 6(2)). However, the inverse situation is also envisaged, under which the Member States may 'hide' behind the institutional veil of the Union. For example, if they implement binding decisions or authorisations they could be freed of international responsibility (cf. Article 17). Hence, the internal division of competences is certainly relevant for the allocation of responsibility, albeit perhaps more as an exception than as the standard rule. Of course, in the implementation of the responsibility, there is a limit; the DARIO also stipulates that 'the responsible international organisation may not rely on its rules as justification for failure to comply with its obligations' (Article 32(1)).

Another set of questions relate to the development of the European External Action Service and to the emerging diplomatic service in third countries and the changing status of the EU in some international organizations. The applicability of

76 Defined in Draft Art. 2 as 'in particular, the constituent instruments, decisions, resolutions and other acts of the organization adopted in accordance with those instruments, and established practice of the organization'. 
'state rules' in this area to the EU has hardly been touched upon in academic writings.

These are just some first thoughts that come to mind when we consider the (planned) increasing activities of the Union at the global level. Given the particularities of CFSP/CSDP these issue deserve special attention in the study of the international responsibility of international organizations. ${ }^{77}$

$77 \quad$ Please see chapter X by Naert in this volume. 